\title{
Sistem Utang Piutang Pupuk Dibayar Gabah di Jember Perspektif Fiqih Muamalah dan Hukum Positif
}

\author{
Siti Muhlisah ${ }^{1}$ \\ ${ }^{1}$ Fakultas Syariah, IAIN Jember. E-mail: sitimuhlisah101014@gmail.com
}

\begin{tabular}{|c|c|}
\hline Article & Abstract \\
\hline $\begin{array}{l}\text { How to cite: } \\
\text { Siti Muhlisah, 'Sistem } \\
\text { Utang Piutang Pupuk } \\
\text { Dibayar Gabah di Jember } \\
\text { Perspektif Fiqih } \\
\text { Muamalah dan Hukum } \\
\text { Positif' (2020) Vol. } 1 \text { No. } 3 \\
\text { Rechtenstudent Journal } \\
\text { Fakultas Syariah IAIN } \\
\text { Jember. } \\
\text { Histori artikel: } \\
\text { Submit } 12 \text { September } \\
\text { 2020; Diterima 20 } \\
\text { November 2020; } \\
\text { Diterbitkan } 7 \text { Desember } \\
2020 \\
\text { ISSN: } \\
\text { 2723-0406 (media cetak) }\end{array}$ & 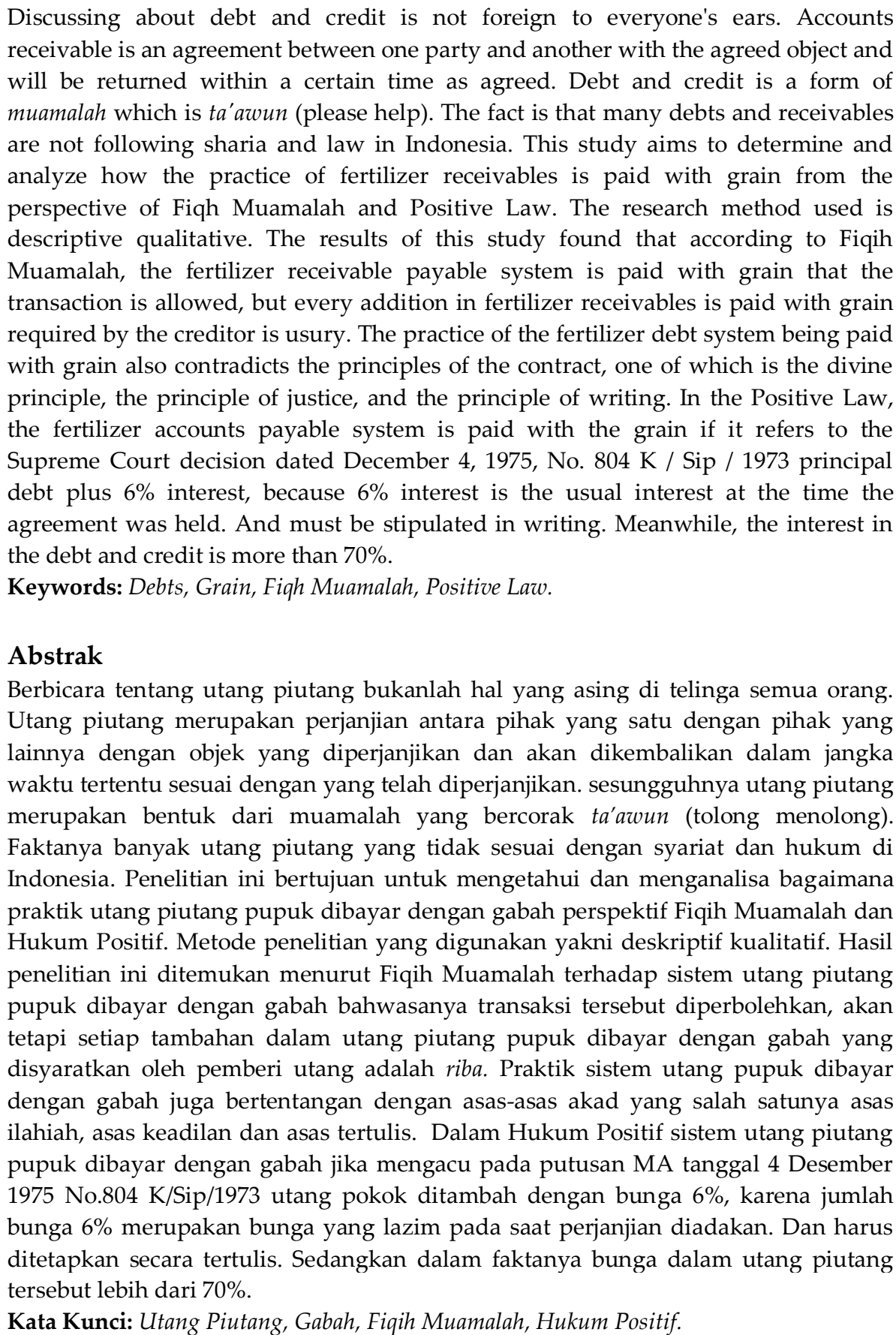 \\
\hline
\end{tabular}




\section{Pendahuluan}

Islam adalah agama yang sempurna, kompleks dan dinamis yang mengatur aspek kehidupan manusia, baik dari segi akidah, ibadah, akhlak maupun muamalah. Ajaran Islam memerintahkan secara eksplisit kepada umat manusia untuk memegang nilai-nilai ajaran Islam secara kaffah (total), menyeluruh, dan utuh. Mereka diperintahkan melaksanakan ajaran yang berkaitan dengan kewajiban individu kepada Allah Swt, dan juga berkaitan dengan kewajiban individu terhadap lingkungan dan sesama anggota masyarakat lainnya. ${ }^{1}$

Manusia adalah mahkluk sosial, yaitu mahkluk yang berkodrat hidup dalam masyarakat, sebagai mahkluk sosial manusia memerlukan adanya manusia-manusia yang lain yang bersama-sama hidup bersama masyarakat. Di dalam bermasyarakat, kita saling membutuhkan satu sama lain. Disadari atau tidak untuk mencukupkan kebutuhan-kebutuhan hidupnya, di tempat manapun setiap orang akan melakukan perbuatan dalam hubungan dengan orang lain dan itu disebut Muamalah. ${ }^{2}$ Dalam melakukan akad maka haruslah secara baik dan benar yang sesuai dengan hukum-hukum Islam dan Hukum Positif, di mana hal tersebut dilakukan dengan tujuan agar mencegah kerusakan pada manusia dan mendatangkan kemaslahatan bagi mereka, mengarahkan mereka pada kebenaran, keadilan dan kebijakan, serta menerangkan jalan yang harus dilalui oleh manusia. ${ }^{3}$

Barang siapa yang memberikan sesuatu kepada seseorang dengan harapan orang itu akan membalas dengan memberikan yang lebih banyak dari pada yang telah diberikan, maka pemberian yang demikian yang tidak berpahala di sisi Allah Swt. Tambahan di sini adalah sesuatu yang diharamkan oleh syariat Islam, baik diperoleh dengan cara penjualan, penukaran atau peminjaman yang berkenaan dengan riba, contoh menjual 1 dinar dengan 2 dinar, menukar gandum $5 \mathrm{~kg}$ dengan $8 \mathrm{~kg}$.

Masyarakat di lingkungan Sukosari, Kecamatan Sukowono, Kabupaten Jember telah melakukan praktik pinjam meminjam atau utang piutang pupuk yang dibayar dengan gabah ini sudah berlangsung sejak lama, mereka melakukan kegiatan ini untuk saling tolong menolong dan membantu sesama manusia. Seperti biasa, orang yang mau melakukan pinjaman mendatangi kreditur (pemberi utang) untuk meminjam pupuk dengan jumlah tertentu. Pemberi utang memberikan pinjaman kepada debitur (penerima pinjaman) sesuai dengan yang diinginkan peminjam. Namun dalam praktiknya kali ini kreditur (pemberi utang) memberikan persyaratan kepada debitur (penerima pinjaman) sesuai yang disepakati, di sini pemberi utang berkuasa atas transaksi utang piutang ini, pengutang hanya mematuhi peraturan dan persyaratan yang sudah dibuat oleh pemberi utang.

Utang piutang yang terjadi di Desa Sukosari, Kecamatan Sukowono, Kabupaten Jember, debitur (pengutang) meminjam pupuk kepada pemberi utang. Orang yang memberi utang (kreditur) memberikan harga pupuk dengan lebih tinggi dari harga pasaran, dan dalam hal pengembalian pembayaran tersebut dengan menggunakan gabah yang sudah kering, di mana orang yang memberi utang membeli harga gabah itu lebih murah dari harga pasaran, dilihat dari kualitas padi kering/gabah tersebut. Sekitar 70\% keuntungan yang diambil oleh pemberi utang.

\footnotetext{
${ }^{1}$ Jusmaliani, Bisnis Berbasis Syariah (Jakarta : Bumi Aksara, 2008), 21.

${ }^{2}$ Ahmad Azhar Basyir, Asas-asas Hukum Muamalah (Yogjakarta : UII Press, 2000), 11.

${ }_{3}$ Amrullah Ahmad, Demensi Hukum Islam dan Sistem Hukum Nasional, ( Jakarta : Gema Insani Press, 1996), 104.
} 
Oleh karena itu, untuk mengetahui praktik pelaksanaannya dan secara jelas tentang aplikasinya, maka diperlukan penelitian yang dimaksud untuk mengetahui korelasi utang piutang dalam Islam atau yang terdapat dalam fiqih muamalah maupun hukum positif agar dapat dijadikan landasan umat Islam dalam kegiatan utang piutang. Dari uraian di atas, tampaklah bahwa beberapa permasalahan yang perlu dikaji secara terperinci dan detail. Mengingat masalah ini sering terjadi dalam masyarakat di Desa Sukosari, Kecamatan Sukowono, Kabupaten Jember, maka perlu untuk dibahas agar dengan bahasan ini diketahui secara jelas status hukumnya.

Berangkat dari uraian di atas maka penelitian ini akan difokuskan pada masalah utang piutang pupuk yang terjadi di Desa Sukosari, Kecamatan Sukowono, Kabupaten Jember dalam bentuk karya ilmiah.

\section{Rumusan Masalah}

Adapun permasalahan yang diangkat menjadi pokok masalah sebagai berikut :

1. Bagaimana praktik dan faktor apa saja yang melatarbelakangi sistem utang piutang pupuk dibayar dengan gabah di Desa Sukosari, Kecamatan Sukowono, Kabupaten Jember?

2. Bagaimana sistem utang piutang pupuk dibayar dengan gabah di Desa Sukosari, Kecamatan Sukowono, Kabupaten Jember Perspektif Fiqih Muamalah ?

3. Bagaimana sistem utang piutang pupuk dibayar dengan gabah di Desa Sukosari, Kecamatan Sukowono, Kabupaten Jember Perspektif Hukum Positif?

\section{Metode Penelitian}

Pendekatan Jenis Penelitian : Pendekatan penelitian yang digunakan dalam penelitian ini adalah pendekatan kualitatif (field Research), yaitu suatu prosedur penelitian yang menghasilkan data deskriptif berupa tulisan dan perilaku yang diamati dari subyek itu sendiri. ${ }^{4}$ Jenis penelitian yang digunakan dalam penelitian ini adalah studi kasus yaitu merupakan pengujian secara rinci terhadap suatu latar, satu subyek, atau peristiwa tertentu. Dalam penelitian ini, dititik beratkan pada Fiqih muamalah dan Hukum Positif tentang sistem utang piutang pupuk dibayar dengan gabah.

\section{Hasil dan Pembahasan}

\section{Praktik dan Latar belakang Sistem Utang Piutang Pupuk Dibayar Gabah}

Pola Sistem dan faktor utang piutang pupuk dibayar dengan gabah di Desa Sukosari yakni Pengutang yang membutuhkan pupuk mendatangi pemberi utang dan mengutarakan maksud bahwa ingin meminjam pupuk, Harga pupuk dinaikan dari harga pasaran pupuk sekitar $70 \%$ oleh pemberi utang, untuk pupuk Urea harga yang diberikan salah satu pemberi utang pupuk di Desa Sukosari, Kecamatan Sukowono, Kabupaten Jember ini senilai Rp. 310.000,00 dan untuk pupuk ZA senilai Rp. 280.000,00. Sedangkan pada harga pasaran pupuk tersebut untuk pupuk Urea Rp. 180.000,00 dan untuk pupuk ZA seharga Rp. 150.000,00. dan pada saat pengembaliannya pengutang akan menggantinya dengan gabah kering yang akan di beli lebih murah oleh pemberi utang. Dalam utang piutang pupuk yang terjadi di Desa Sukosari, Kecamatan Sukowono, Kabupaten Jember tersebut tidak dilakukan dengan perjanjian tertulis atau mendatangkan saksi, hanya saja pemberi utang pupuk di Desa

\footnotetext{
${ }^{4}$ Moh. Nazir, Metode Penelitian (Bogor: Ghalia Indonesia, 2014), 228.
} 
Sukosari menulis di buku pribadinya dan hanya memuat nama pengutang dan besar pinjaman pupuk yang dipinjamkan.

Dari hasil wawancara inilah peneliti dapat mengetahui bahwa faktor masyarakat melakukan utang piutang pupuk dibayar dengan gabah karena masyarakat kekurangan modal untuk perawatan padinya. Setelah masa panen lewat dan tiba pada musim bertanam, para petani/buruh tani sudah tidak memiliki cadangan modal untuk melengkapi segala kebutuhan yang diperlukan untuk bercocok tanam dan perawatannya. Biasanya modal yang ada hanya cukup untuk pengelolaan lahannya saja, sedangkan untuk pemupukannya mereka sudah tidak memiliki modal lagi. Dalam keadaan seperti itu mereka berutang pupuk pada pedagang pupuk/pemberi utang pupuk, agar tanaman padi yang telah ditanam di sawah tumbuh dengan subur dan menghasilkan panen yang memuaskan, menurut pendapat mereka tidak ada jalan lain kecuali berutang kepada pemberi utang pupuk ataupun orang yang dipandang paling kaya di Desa Sukosari, karena hal tersebut lebih mudah para pengutang lakukan.

Dari pemaparan di atas peneliti menganggap bahwa utang piutang pupuk dibayar dengan gadah di Desa Sukosari, Kecamatan Sukowono, Kabupaten Jember ini bukanlah akad utang piutang melainkan akad jual beli yang ditangguhkan. Jual beli tangguh adalah jual beli yang pembayaran harganya tidak tunai, baik dibayar sekaligus pada tanggal tertentu (ke depan) atau diangsur dalam jangka waktu tertentu, namun masyarakat umumnya menyebutnya akad utang piutang, dari penjelasan macam-macam jual beli yang ditangguhkan di atas, peneliti menyimpulkan bahwasanya utang piutang pupuk dibayar dengan gabah di Desa Sukosari untuk penambahan yang disyaratkan oleh pihak pemberi utang termasuk ke dalam bai' murabahah, dimana pihak pemberi utang boleh mengambil keuntungan yang tidak dibatasi menurut hukum Islam.

Praktik sistem utang piutang pupuk dibayar dengan gabah di Desa Sukosari ini jika dilihat pembayaran harganya tidak tunai maka praktik tersebut lebih condong dalam $B a^{\prime} i$ Mu'ajjal, yakni jual beli yang pembayaran harganya tidak tunai, baik dibayar sekaligus pada tanggal tertentu (ke depan) atau diangsur dalam jangka waktu tertentu. Karena dalam praktiknya yang terjadi pemberi utang pupuk menangguhkan pembayarannya ketika pengutang sudah tiba pada masa panen, walaupun ada sebagian dari pemberi utang pupuk ada yang menagih sebelum masa panen tiba.

Para ulama berbeda pendapat dalam bai' mu'ajjil ada ulama yang tidak memperbolehkan (Abu Bakar al-Jashash (dari kalangan hanafiyah). Ibn Hazm al-Zhahiri dan Zain al-Abidin 'Ali Ibn al Husein, sebagaimana dinukilkan al-Syaukani dan Imam Yahya) dengan alasan penambahan harga karena pembiayaan tidak tunai termasuk riba yang diharamkan. Adapun ulama yang memperbolehkan (Hanafiah, Malikiyah, Syafi'iyah dan Hambali) dengan alasan hukum memperoleh keuntungan dalam akad jual beli adalah boleh, baik keuntungan tersebut diperoleh dalam jual beli tunai maupun jual beli tangguh ataupun angsur.

Dengan adanya perbedaan pendapat maka peneliti menyimpulkan bahwa jual beli secara tangguh diperbolehkan dengan memahami alasan-alasan yang telah dijelaskan oleh Ulama Hanafiah, Malikiyah, Syafi'iyah dan Hambali karena praktik yang terjadi di Desa Sukosari bukan merupakan piutang (pupuk dibayar dengan pupuk) melainkan masuk ke dalam jual beli yang ditangguhkan (pupuk dibayar dengan gabah), di mana dalam prinsip jual beli penjual bebas untuk menentukan harga yang dia kehendaki. 
Adapun analisis praktik sistem utang piutang pupuk dibayar dengan gabah di Desa Sukosari yakni dalam penelitian ini penulis menemukan suatu temuan yang terjadi dilapangan yaitu terkait praktik sistem utang piutang pupuk dibayar dengan gabah ini bukanlah merupakan akad utang piutang melainkan jual beli tangguh karena utang piutang yang terjadi dalam Desa tersebut pupuk yang dipinjam akan dibayar dengan gabah, sedangkan pada prinsipnya utang piutang barang yang dipinjam harus dikembalikan dengan jenis yang sama, misalkan meminjam pupuk dibayar dengan pupuk. Masyarakat menyebut utang piutang karena kebiasaan atau sudah menjadi keumuman yang terjadi di masyarakat. Dalam praktiknya sistem utang piutang pupuk dibayar dengan gabah ini juga tidak dilakukan secara tertulis, pemberi utang hanya mencatat dengan mencantumkan nama pengutang, dan juga besaran pupuk yang telah dipinjam oleh pengutang. Kedua belah pihak (pemberi utang dan pengutang) saling percaya sehingga tidak melakukan perjanjian secara tertulis. Padahal di dalam Al-Qur' an dijelaskan bahwasanya siapa saja yang melakukan muamalah secara tidak tunai hendaklah ditulis (al-Baqarah ayat 282) dan Dalam pasal 1767 ayat 3 KUH Perdata tambahan harus di tetapkan secara cara tertulis, maka dalam hal utang piutang juga harus dilakukan secara tertulis. Tujuan dilakukannya secara tertulis, tidak lebih untuk memudahkan pembuktian besaran tambahan/bunga.

\section{Sistem Utang Piutang Pupuk Dibayar Gabah Perspektif Fiqih Muamalah}

Sistem utang piutang pupuk dibayar dengan gabah yang terjadi di Desa Sukosari terdapat dua persyaratan yang diberikan pemberi utang kepada pengutang yakni mensyaratkan untuk dikembalikan dengan gabah kering dan juga gabah tersebut harus dibeli lebih murah oleh pihak pemberi utang. Dalam jual beli bersyarat terdapat perbedaan pendapat ada yang memperbolehkan ada pula yang tidak memperbolehkan, adapun alasannya yakni :

1. Diperbolehkan : Ulama Hanabilah menyatakan sahnya akad jual beli dengan syarat, dengan catatan syarat yang diberlakukan hanya satu saja. Syarat merupakan bagian dari tujuan akad (muqtadla al-aqdi). Syarat berada di luar ketentuan akad, dan tidak bertentangan dari tujuan akad. Syarat ini umumnya disampaikan agar tercapai kemaslahatan syar'i dan objek transaksi. Apabila syarat disertai dengan penyebutan pengecualian manfaat tertentu yang bersifat mubah terhadap objek transaksi.

2. Tidak diperbolehkan : Jika syarat membatalkan tujuan utama dengan transaksi. Bila salah satu orang yang bertransaksi mensyaratkan adanya akad lain jual beli. Menguntungkan akad pada sesuatu yang belum pasti terjadi.

Dengan adanya perbedaan pendapat maka peneliti menyimpulkan bahwa jual beli bersyarat yang terjadi di Desa Sukosari terhadap sistem utang piutang pupuk dibayar dengan gabah tidak diperbolehkan karena terdapat dua persyaratan yang diberikan oleh pemberi utang pupuk kepada pengutang yakni mensyaratkan untuk dikembalikan dengan gabah kering dan juga gabah tersebut harus dibeli lebih murah oleh pihak pemberi utang.

Sistem utang piutang pupuk dibayar dengan gabah di Desa Sukosari, Kecamatan Sukowono, Kabupaten Jember masih belum dilakukan secara tertulis, jika mengacu pada Q.S Al-Baqarah (2) : 282; jika melakukan muamalah secara tidak tunai untuk waktu yang ditentukan, hendaklah kamu menulisnya. Persaksikanlah dengan dua orang saksi dari orangorang lelaki (di antaramu). Jika tidak ada dua orang lelaki, maka boleh seorang lelaki dan dua orang perempuan dari saksi-saksi yang kamu ridhai, supaya jika kamu lupa maka seseorang yang mengingatnya. 
Praktik sistem utang piutang pupuk dibayar dengan gabah di Desa Sukosari, Kecamatan Sukowono, Kabupaten Jember ini bukanlah utang piutang melainkan jual beli yang ditangguhkan dan juga merupakan jual beli bersyarat. Para ulama beda pendapat terhadap jual beli bersyarat ada yang memperbolehkan ada pula yang tidak memperbolehkan, dari pemaparan di atas peneliti menarik kesimpulan bahwa jual beli bersyarat yang terjadi di Desa Sukosari ini tidak diperbolehkan karena terdapat dua persyaratan yang diberikan oleh pemberi utang pupuk kepada pengutang yakni mensyaratkan untuk dikembalikan dengan gabah kering dan juga gabah tersebut harus dibeli lebih murah oleh pihak pemberi utang.

\section{Sistem Utang Piutang Pupuk Dibayar Gabah Perspektif Hukum Positif}

Sistem utang piutang pupuk dibayar dengan gabah perspektif hukum postif (KUHPerdata). Mengenai pengertian dari hukum perdata, para pakar sarjana memberikan arti yang berbeda-beda. Pendapat pakar sarjana hukum tersebut antara lain:

a. Menurut Prof. Subekti, S.H., hukum perdata dalam arti yang luas meliputi semua hukum "privat material" yaitu segala hukum yang pokok yang mengatur kepentingankepentingan perseorangan. ${ }^{5}$

b. Menurut Prof. Dr. R. Wirjono Prodjodikoro, S.H., hukum perdata adalah suatu rangkaian hukum antara orang-orang atau badan-badan hukum satu sama lain tentang hak dan kewajiban. ${ }^{6}$

c. Menurut Prof. Dr. Sudikno Mertokusumo, S.H., hukum perdata adalah hukum antar perorangan yang mengatur hak dan kewajiban perorangan yang satu terhad ap yang lain di dalam hubungan keluarga dan di dalam pergaulan masyarakat. ${ }^{7}$

Dalam pasal 1754 KUHPerdata menyebutkan utang piutang adalah perjanjian dengan mana pihak yang satu memberikan pada pihak yang lain suatu jumlah tertentu barang-barang yang menghabiskan karena pemakaiannya dengan syarat pihak belakangan ini akan mengembalikan sejumlah yang sama dari macam dan keberadaan yang sama pula. Dari definisi tersebut peneliti menyimpulkan bahwa sistem utang piutang pupuk dibayar dengan gabah di Desa Sukosari, Kecamatan Sukowono, Kabupaten Jember ini bukan merupakan akad utang piutang (Qardh) melainkan akad jual beli tangguh, karena pengutang yang meminjam pupuk, nanti pada saat pengembalian bukan dengan pupuk lagi melainkan dengan gabah yang sudah kering yang disyaratkan oleh pemberi utang.

Dalam KUHPerdata ketentuan mengenai syarat tidak diatur dibagian perjanjian tetapi dibagian perikatan, yakni pada pasal-pasal 1253-1267 KUH Perdata. Pengertian kata syarat diterapkan dalam kaitannya dengan syarat menangguhkan dan syarat membatalkan dan merujuk selalu pada tujuan untuk berlangsungnya suatu peristiwa hukum yang bergantung pada peristiwa yang belum tentu terjadi atau tak terduga. Syarat yang bertujuan melakukan sesuatu yang tidak mungkin terlaksana, sesuatu yang bertentangan dengan kesusilaan baik, atau sesuatu yang dilarang oleh undang-undang, adalah batal dan berakibat bahwa perjanjian yang digantungkan padanya.

Dengan demikian, persyaratan yang diberikan oleh pemberi utang jika dilihat di dalam hukum positif diperbolehkan, karena persyaratan yang diberikan oleh pemberi utang tidak bertentangan dengan kesusilaan baik, atau sesuatu yang dilarang oleh undang-undang, yakni

\footnotetext{
${ }^{5}$ Subekti, Pokok-pokok Hukum Perdata (Jakarta: Intermasa), 9.

${ }^{6}$ R. Wirjono Prodjodikoro, Asas-asas Hukum Perdata (Jakarta: Sumur Bandung, 1992), 10-11.

7 Sudikno Mertokusumo, Mengenal Hukum Suatu Pengantar (Yogjakarta: Liberty, 1986), 108.
} 
persyaratan yang diberikan oleh pemberi utang kepada pengutang untuk membayar pupuk tersebut dengan gabah, dan gabah tersebut harus di jual kepada pemberi utang.

Perikatan dengan ketetapan waktu menurut pasal 1269 yakni apa yang harus dibayar pada suatu waktu yang ditentukan tidak dapat ditagih sebelum waktu tersebut datang, tetapi apa yang telah dibayar sebelum waktu itu datang, tidak dapat diminta kembali. Namun pada praktik yang terjadi di Desa Sukosari, Kecamatan Sukowono, Kabupaten Jember ini sebelum masa panen atau pembayaran pupuk yang ditentukan dalam akad pihak pemberi utang menagih pembayaran tersebut.

Perikatan dengan ketetapan waktu menurut pasal 1269 yakni apa yang harus dibayar pada suatu waktu yang ditentukan tidak dapat ditagih sebelum waktu tersebut datang, tetapi apa yang telah dibayar sebelum waktu itu datang, tidak dapat diminta kembali. Namun pada praktik yang terjadi di Desa Sukosari, Kecamatan Sukowono, Kabupaten Jember ini sebelum masa panen atau pembayaran pupuk yang ditentukan dalam akad pihak pemberi utang menagih pembayaran tersebut. Dalam pasal 1767 ayat 3 KUHPerdata tambahan harus di tetapkan secara cara tertulis, maka dalam hal jual beli tangguh juga harus dilakukan secara tertulis. Tujuan dilakukannya secara tertulis, tidak lebih untuk memudahkan pembuktian jika terjadi suatu sengketa.

\section{Kesimpulan}

Praktik utang piutang pupuk yang terjadi di Desa Sukosari, Kecamatan Sukowono, Kabupaten Jember yakni pihak pengutang mendatangi pihak pemberi utang dan mengutarakan maksud dan tujuannya untuk meminjam pupuk serta besaran yang akan dipinjam, kemudian pihak pemberi utang memberikan pinjaman sesuai dengan permintaan pengutang. Namun kecenderungan terhadap praktik utang piutang ini adalah setiap pemberi utang memberikan pinjaman berupa barang (pupuk) dengan menaikkan harga pupuk tersebut $70 \%$ dari harga pasaran. Pihak pemberi utang mensyaratkan dalam pengembaliannya dengan menggunakan gabah kering, yang nantinya gabah tersebut akan dibeli lebih murah oleh pihak pemberi utang. Salah satu faktor yang menyebabkan pengutang melakukan utang piutang tersebut karena kebutuhan yang sangat mendesak atau kekurangan modal untuk perawatan padinya. Setelah masa panen lewat dan tiba pada musim bertanam, para petani/buruh tani sudah tidak memiliki cadangan modal untuk melengkapi segala kebutuhan yang diperlukan untuk bercocok tanam dan perawatannya. Biasanya modal yang ada hanya cukup untuk pengelolahan lahannya saja, sedangkan untuk pemupukannya mereka sudah tidak memiliki modal lagi.

Menurut tinjauan Fiqih Muamalah terhadap sistem utang piutang pupuk dibayar dengan gabah di Desa Sukosari bahwasanya transaksi tersebut tidak diperbolehkan, karena sebenarnya itu bukan akad utang piutang meskipun masyarakat menyebutnya utang piutang. Melihat dari pengertian utang piutang merupakan perjanjian antara pihak yang satu dengan pihak yang lainnya dengan objek yang perjanjikan dan akan dikembalikan dalam jangka waktu tertentu sesuai dengan perjanjian (barang dibayar dengan barang yang sejenis/pupuk dibayar dengan pupuk). Sedangkan jual beli tangguh adalah jual beli non tunai yang pada hakikatnya untuk dimiliki bukan untuk dimanfaatkan (barang dibayar dengan barang yang bukan sejenis/pupuk dibayar dengan gabah) dan pembayarannya ditangguhkan, dimana dalam jual beli penjual tidak ada batasan untuk menentukan keuntungan. Dalam pengembalian yang disyaratkan termasuk ke dalam jual beli bersyarat. Para ulama berbeda 
pendapat terkait jual beli bersyarat ada yang tidak memperbolehkan dan ada yang memperbolehkan dengan alasan persyaratannya tidak boleh lebih dari satu. Tetapi praktik yang terjadi terdapat dua persyaratan yang diberikan oleh pemberi utang pupuk kepada pengutang yakni mensyaratkan untuk dikembalikan dengan gabah kering dan juga gabah tersebut dibeli lebih murah oleh pihak pemberi utang.

Menurut Hukum Positif terhadap sistem utang piutang pupuk dibayar dengan gabah di Desa Sukosari ini diperbolehkan. Asalkan persyaratan yang diberikan oleh pemberi utang tidak bertentangan dengan kesusilaan baik, atau sesuatu yang dilarang oleh Undang-Undang. Perikatan dengan ketetapan waktu menurut pasal 1269 yakni apa yang harus dibayar pada suatu waktu yang ditentukan tidak dapat ditagih sebelum waktu tersebut datang, tetapi apa yang telah dibayar sebelum waktu itu datang, tidak dapat diminta kembali. Namun pada praktik yang terjadi di Desa Sukosari, Kecamatan Sukowono, Kabupaten Jember ini sebelum masa panen atau pembayaran pupuk yang ditentukan dalam akad pihak pemberi utang menagih pembayaran tersebut.

\section{Daftar Pustaka}

\section{Buku}

Azhar Basyir, Ahmad. 2000. Asas-asas Hukum Muamalah. Yogjakarta: UII Press.

Ahmad, Amrullah. 1996. Demensi Hukum Islam dan Sistem Hukum Nasional. Jakarta: Gema Insani Press.

Bungin, Burhan. 2007. Metodologi Penelitian Kualitatif. Jakarta: PT. Raja Grafindo Persada.

Departemen Pendidikan Nasional. 2002. Kamus Besar Bahasa Indonesia. Jakarta: Balai Pustaka.

Dwi Astuti, Eni. 2010. Ziyadah Dalam Utang Piutang. IAIN Wali Songo: Semarang.

Hasan, A. 2000. Terjemah Bulugul Marom. Jakarta: Pustaka Tamaam.

Harisudin, Noor. 2014. Fiqih Muamalah I. Surabaya : Pena Salsabila

Mardani. 2011. Fiqih Ekonomi Syariah (Fiqih Muamalah). Jakarta : Kencana.

Nazir, Moh. 2014. Metode Penelitian. Bogor: Ghalia Indonesia.

Sumitro, Warkum. 2005. Perkembangan Hukum Islam Di Tengah Kehidupan Sosial Politik Di Indonesia. Jawa Timur: Bayumedia Publishing.

Syafe'i, Rachmat. 2004. Fiqih Muamalah. Bandung: Pustaka Setia.

Supramono, Gatot. 2013. Perjanjian Utang Piutang. Jakarta: Kencana Prenada Media Group.

Tjitrosudibio, R. Subekti. 2009. Kitab Undang-undang Hukum Perdata. Jakarta: Pradnya Paramita.

Qardhawi, Yusuf. 2001. Norma dan Etika Ekonomi Syari'ah. Jakarta: Gema Insani Press. 